\title{
Dokument
}

\section{John McCain: \\ Vi kan skabe en bedre verden}

Præsident Truman sagde engang om Amerika, at "Gud har ført os frem til vor nuværende magt- og styrkeposition med tanke på et højere formål”. I hans tid var dette formål at inddæmme kommunismen og skabe de strukturer af fred og velstand, der kunne bane sikker vej igennem Den Kolde Krig. Nu er det vor tur. Vi står over for en række nye muligheder, men også over for nye farer. Den videnskabelige og teknologiske udvikling har bragt os velstand uden fortilfælde, udryddet sygdomme og mindsket lidelser for millioner. Vi har i vor levetid chancen for at løfte verden til nye højder for menneskelig trivsel. Men samme teknologier har også medført nye alvorlige risici og udrustet nogle få fanatikere med muligheden for at myrde millioner af uskyldige, ligesom de har resulteret i en global in- dustrialisering, der på længere sigt vil kunne true vor planet. Skal vi imødegå den udfordring, må vi kunne forstå den verden vi lever i, og forstå, at De Forenede Stater har en altafgørende rolle at spille i udformningen af dens fremtid.

I det 21. århundrede må De Forenede Stater påtage sig et lederskab, ganske som vi måtte det i Trumans dage. Men at påtage sig et lederskab i dag indebærer noget helt andet end i årene efter Anden Verdenskrig, da Europa og de øvrige demokratier stadig var i færd med at rejse sig efter krigens ødelæggelser, og De Forenede Stater var den eneste demokratiske supermagt i verden.

I dag står vi ikke alene. Den Europæiske Union har en magtfuld kollektiv stemme, og der findes store nationer som Indien og Japan, Australien og Brasilien, Sydkorea og

USA's store magt "betyder ikke, at vi er i stand til at gøre alt, hvad vi ønsker. Ej heller bør vi gå ud fra, at vi har al den visdom og viden, der skal til for at få succes..." sagde Republikanernes præsidentkandidat, John McCain, i en tale til World Affairs Council i Los Angeles den 26. marts 2008. Udenrigs bringer et uddrag. 
Sydafrika, Tyrkiet og Israel for at nævne nogle få af verdens førende demokratier. Der findes derudover de stadig mere magtfulde nationer Kina og Rusland, som udøver stor indflydelse i det internationale system.

I en sådan verden, hvor magt i enhver forstand har en bredere og mere jæun fordeling, kan De Forenede Stater ikke påtage sig en ledende rolle i kraft af sin magt alene. Vi må være politisk, økonomisk og militært stærke. Men vi må også lede ved at gøre vor sag tiltrækkende for andre, ved endnu engang at demonstrere frihedens og demokratiets dyder, ved at forsvare det internationale civiliserede samfunds regler og ved at bistå med at skabe de nye internationale institutioner, der skal til for at fremme freden, og de friheder vi sætter så højt. Måske vil det højeste udtryk for lederskab i vore dages verden bestå $i$, at vi forstår at acceptere og opfylde vore forpligtelser som en stor nation.

At være en god og pålidelig allieret for vore demokratiske partnere er en af disse forpligtelser. Vi kan ikke opbygge en varig fred, der alene bygger på vor egen frihed, og ej heller er dette vort ønske. Vi er nødt til at styrke de globale alliancer, som vi indgår i, og gøre dem til kernen i en ny global kontrakt - et Demokratiernes Forbund - som kan udnytte den potentielt enorme indflydelse hos verdens 100 demokratier til at fremme vore værdier og forsvare vore fælles interesser. Det centrale i denne kontrakt må bestå i gensidig respekt og tillid.

Vi bør her huske på, hvad Uafhængighedserklæringens grundlæggere indskærpede: At vi skal "udvise behørig respekt over for menneskehedens mange anskuelser". Vor store magt betyder ikke, at vi er i stand til at gøre alt, hvad vi ønsker. Ej heller bør vi gå ud fra, at vi har al den visdom og viden, der skal til for at få succes. Vi er nødt til at lytte til vore demokratiske allieredes synspunkter og respektere deres kollektive vilje. Når vi frem til, at international handling er påkrævet, det være sig militært, økonomisk eller diplomatisk, må vi tilstræbe at overbevise vore venner om, at vi har ret. Til gengæld bør vi også være villige til at kunne lade os overbevise af dem.

Amerika må være en global mønsterborger, hvis det er vort ønske, at andre skal se op til os som forbillede. Vor opførsel indadtil har konsekvenser for, hvordan vi bliver opfattet i udlandet. Vi må bekæmpe terrorister, men vi må samtidig værne om de rettigheder, som vort samfund bygger på. Vi kan ikke udsætte de terrormistænke, vi har pågrebet, for tortur eller behandle dem inhumant. Vi bør efter min mening lukke Guantánamo og arbejde sammen med vore allierede om at skabe en ny international forståelse for, hvad vi stiller op med de farlige individer, som tilbageholdes under vor kontrol. 
Også på det internationale plan findes der noget, der hedder et godt medborgerskab. Vi er nødt til at være gode forvaltere af vor planet og lægge vore kræfter sammen med andre nationers for at bidrage til at bevare vort fælles hjem. Den globale opvarmning udsætter os for risici, der ikke kender til grænser. Vi og verdens øvrige nationer må tage alvorligt fat på en markant reduktion af drivhusgas-udledningerne i de kommende år - ellers vil vi komme til at aflevere en stærkt forkrøblet verden til vore børnebørn. Vi har brug for en ny aftale, der kan afløse Kyoto-traktaten, et cap-and-trade-system, der kan sikre, at vi redder miljøet på en økonomisk ansvarlig måde. Vi amerikanere må i kraft af vort eksempel føre an og tilskynde resten af verden til at deltage, navnlig de fremvoksende nye økonomiske magtcentre, Kina og Indien.

For fireethalvt årti siden betegnede John Kennedy Latinamerikas folk som vore "gamle trofaste venner, som vi er forenet med i kraft af historie, fælles erfaringer og vort faste forsæt om at fremme den amerikanske civilisations værdier". Med globaliseringen er vor halvkugle vokset snævrere sammen og er blevet mere integreret og mere gensidigt afhængig. Latinamerika har i dag en stadig mere vital betydning for De Forenede Staters fremtidsmuligheder. Amerikanere i nord og syd deler en fælles geografi og en fælles skæbne. Latinamerikas lande er naturlige partnere for De Forenede Stater, som de er det for vor nordlige nabo, Canada.

Forholdet til vore sydlige naboer må bygge på gensidig respekt $\mathrm{og}$ ikke på en imperiemagts impulser eller på antiamerikansk demagogi. De forhåbninger, som den nord-, central- og sydamerikanske livsform vækker til live, er for store til det. Jeg tror på, at de to amerikanske kontinenter kan og må blive modellen for det 21. århundredes nye relation mellem Nord og Syd. Vor halvkugle kan blive den første fuldstændigt frie demokratiske verdensdel, hvor handelssamkvem foregår frit på tværs af alle grænser, og hvor retsstatsprincipper og det frie markeds magt fremmer sikkerhed og velstand for alle.

\section{Fælles interesser med Kina}

I vore dages verden flytter magten østpå: Asien-Stillehavsregionen er på vej frem. Sammen med Japan, vor demokratiske partner igennem årtier, kan vi gribe de muligheder, der er til stede i verden, som den udvikler sig, og gøre dette århundrede sikkert, således at det bliver både amerikansk og asiatisk, både velstående og frit. Asien har anstrengt sig enormt igennem de senere årtier. Dets økonomiske præstationer er velkendte. Mindre kendt er det, at der i Asien lever flere mennesker under demokratisk styreform end i nogen anden region af verden. 


\section{DOKUMENT}

At udvikle det rette forhold til Kina vil blive en central udfordring for den næste amerikanske præsident. Kinas seneste fremgang har reddet flere mennesker ud af fattigdom, end det har været tilfælde på noget andet tidspunkt i historien. Men Kinas nye magt indebærer både ansvar og forpligtelser. Kina kan troværdiggøre sin påstand om at være en 'fredelig magt på vej op' ved at øge gennemsigtigheden omkring sin betydelige militære oprustning, ved at samarbejde med verden om at isolere pariastater som Burma, Sudan og Zimbabwe og ved at opgive sine bestræbelser for at etablere regionale fora og økonomiske ordninger, der er lagt an på at udelukke Amerika fra Asien.

Kina og De Forenede Stater er ikke forudbestemt til at skulle blive hinandens modstandere. Vi har talrige overlappende interesser, og vi håber begge på at se vort forhold udvikle sig på en måde, der er til fordel for begge lande og i videre forstand for Asien-Stillehavsregionen og verden. Men indtil Kina tager skridt i retning af politisk liberalisering, vil vort forhold komme til at bygge på periodisk delte interesser snarere end på et solidt grundlag af fælles værdier.

USA vandt ikke Den Kolde Krig ved at gå enegang. Den transatlantiske alliance og samarbejdet med vore partnere verden over gav os sejren. De bånd, der binder os til Europa i henseende til historie, værdier og interesser, er unikke. Opkomsten af et stærkt og selvbevidst EU bør amerikanerne hilse velkommen, på samme måde som vi fortsat støtter et stærkt NATO. Det transatlantiske forholds fremtid bestemmes af, hvordan vi sammen vil møde det 21 . århundredes globale udfordringer: Ved at udvikle en fælles energipolitik, skabe et transatlantisk fællesmarked, der kan binde vores økonomier tættere sammen, imødegå de farer, som et revanchistisk Rusland stiller os overfor, og institutionalisere vort samarbejde på områder som klimaforandringer, international bistand og udbredelse af demokrati.

\section{Krav til Rusland - og Afrika}

Vi bør begynde med at sikre, at G8, gruppen af otte højt industrialiserede lande, igen bliver til en klub for de førende markedsdemokratier. Denne klub bør omfatte Brasilien og Indien, men udelukke Rusland. Snarere end at tolerere Ruslands nukleare afpresning eller cyberangreb bør de vestlige nationer gøre det klart, at NATOs solidaritet er ubrydelig fra Østersøen til Sortehavet, og at organisationens dør står åben for alle de demokratier, der vil forpligte sig i forsvaret for friheden. Afrikas problemer - fattigdom, korruption, sygdom og ustabilitet er velkendte, men i Afrika bør vi i stedet rette fokus mod de lovende perspektiver, der tegner sig i mange af landene på dette kontinent. På 
det politiske, økonomiske og sikkerhedsmæssige niveau må vi indgå i et stærkt engagement med venligtsindede regeringer i hele Afrika, idet vi samtidig insisterer på, at der skal ske forbedringer i forhold til gennemsigtighed og respekt for retsprincipper. Mange afrikanske nationer vil ikke kunne indfri deres sande potentiale, hvis de ikke får hjælp udefra til at bekæmpe indgroede problemer som HIV/aids, der rammer et uforholdsmæssigt stort tal af afrikanere. Jeg vil gøre det til mit mål at udrydde malaria - den værste dræber af afrikanske børn under fem på hele kontinentet. Ud over at redde millioner af liv i en af verdens fattigste regioner vil en sådan kampagne kunne udrette meget for at bedre Amerikas ry i verden.

Sammen med verdens øvrige store magter har vi endvidere en forpligtelse til at bremse og indskrænke udbredelsen af kernevåben. De Forenede Stater og det internationale samfund må arbejde sammen og gøre alt, hvad der står i vor magt, for at inddæmme og afvikle Nordkoreas atomvåbenprogram og for at hindre Iran - en nation, hvis præsident gentagne gange har udtrykt ønske om at udslette Israel fra Jordens overflade - $\mathrm{i}$ at opnå atomvåben.

Vi bør arbejde for at reducere de nukleare arsenaler i hele verden og begynde med vort eget. For 40 år siden gik de fem erklærede atommagter sammen om at støtte Den Nukleare Ikke-Spredningstraktat
(NNPT) og lovede at afslutte våbenkapløbet og indlede skridt imod nuklear nedrustning. Tiden er inde til at tage denne forpligtelse op på ny. Vi behøver ikke alle de våben, der aktuelt befinder sig i vort arsenal. De Forenede Stater bør føre an i de globale bestræbelser for nuklear nedrustning, der er i overensstemmelse med vor vitale interesse og fredens sag.

\section{Trussel fra islamisk terrorisme}

Hvis vi får succes med at samle en global koalition for fred og frihed hvis vi kan påtage os lederrollen ved at tage vore internationale forpligtelser på vore skuldre og anvise en vej for en bedre og mere sikker fremtid for menneskeheden - er jeg overbevist om, at vi som nation vil kunne høste konkrete fordele.

Det vil styrke os at konfrontere vor tids altoverskyggende udfordring: truslen fra den radikale islamiske terrorisme. At denne udfordring er altoverskyggende betyder ikke, at den er den eneste trussel, vi står overfor. Der er mange andre farer i vore dages verden, og vor udenrigspolitik må være smidig og effektiv nok til at kunne tage hånd om alle. Men den trussel, som terroristerne udgør, er unik. Terroristerne er alene om at vie al deres energi, ja tilmed deres eget liv, til mord på uskyldige mænd og kvinder. De er alene om at stræbe efter at anskaffe sig nukleare og andre 
masseødelæggelsesvåben - ikke for at højne deres prestige eller give sig selv en stærkere hånd i verdenspolitikken - men i den hensigt at bruge disse våben imod os, hvor som helst og når som helst de kan. En præsident, som ikke sætter denne trussel over alle andre, fortjener ikke at sidde i Det Hvide Hus, for i givet fald forsømmer han eller hun at tage sin første og fundamentale pligt alvorligt: pligten til at beskytte det amerikanske folk.

Den 11. septembers tragedie belærte os om, at et passivt forsvar alene ikke kan beskytte os. Vi må beskytte vore grænser. Men vi må også have en aggressiv strategi for at konfrontere terroristerne og optrævle deres rodnet, uanset hvor de søger at operere, og nægte dem baser i stater, der er fejlslagne eller på vej til at blive det. I dag opererer alQaeda og andre terrornetværk over hele kloden og lurer på deres chancer i Sydøstasien, Centralasien og i Mellemøsten.

At få overtaget i denne kamp vil kræve langt mere end militær magt. Det vil kræve brug af alle elementer i vor nationale magt: offentligt diplomati, udviklingsbistand, uddannelse og træning af politistyrker, udvidelse af økonomiske muligheder og robuste efterretningskapaciteter. Jeg har opfordret til omfattende forandringer i vor regerings strategi over for den islamiske ekstremisme, herunder afsættelse af langt større ressourcer til integration af de civile bestræbelser for at forhindre konflikter og håndtere de udfordringer, der knytter sig til lande i post-konflikt-situationer. Vort mål må være at vinde 'hjerterne og hjernerne' hos det store flertal af moderate muslimer, som ikke ønsker, at deres fremtid skal kontrolleres af en minoritet af voldelige ekstremister. I denne kamp har stipendiater til studerende en langt større rolle at spille end intelligente bomber.

\section{Stol ikke på forældede autokratier}

Vi er også nødt til at opbygge internationale strukturer for en varig fred, hvor de radikale ekstremister gradvis stilles i skyggen af frihedens og tolerancens mere magtfulde kræfter. Vore bestræbelser i Irak og Afghanistan er i denne henseende af afgørende vigtighed og kan ikke forstås i isolation fra vor mere omfattende strategi. I den plagede og ofte farlige region, som disse to nationer er del af, kan de enten være kilder til ekstremisme og ustabilitet eller med tiden blive bærepiller for stabilitet, tolerance og demokrati.

I årtier var vor strategi for hele Mellemøstregionen at forlade os på, at autokrater kunne sørge for orden og stabilitet. Vi satte vor lid til shahen af Iran, til Egyptens autokratiske herskere, Pakistans generaler, Saudi-Arabiens kongefamilie og selv, for en tid, til Saddam Hussein. I slutningen af 1970'erne begyndte denne strategi at gå op i limningen. 
Shahen blev styrtet af den radikale islamiske revolution, der nu hersker i Teheran. Den efterfølgende gæring i den muslimske verden resulterede i øget ustabilitet. Autokraterne slog desto hårdere ned på alle tilløb til modstand, idet de støttede den islamiske radikalisme i udlandet $\mathrm{i}$ smug i håbet om, at de ikke selv ville blive dens ofre. Det var en giftig og sprængfarlig blanding. Autokraternes undertrykkelse i kombination med de radikale islamisters dogmatiske teologi var opskriften på den fuldendte storm af intolerance og had.

Vi kan ikke længere ligge under for det bedrag, at en fortsat tiltro til disse forældede autokratier er den sikreste satsning. De yder ikke længere nogen varig stabilitet, kun illusionen derom. Vi må ikke handle overilet eller kræve øjeblikkelige forandringer. Men ej heller må vi foregive, at status quo er bæredygtig, stabil og i vor interesse. Forandringer finder sted, uanset om vi vil det eller ej. For os er spørgsmålet alene, om vi vil forme disse forandringer på måder, som kan blive til gavn for menneskeheden, eller om vi vil lade vore fjender udnytte dem til deres hadefulde formål. Vi må bestræbe os på at udvide frihedens magt og rækkevidde ved at bruge vor fulde styrke som et frit folk.

Dette er ikke bare idealisme. Det er realisme i ordets sandeste betydning. Det er verdens demokratier, som vil tilvejebringe de søjler, hvor- på vi kan og må bygge en vedvarende fred.

Ser man på den store bue, der strækker sig fra Mellemøsten gennem Centralasien, det asiatiske subkontinent og frem til Sydøstasien, kan man se demokratiske bærepiller rage op på tværs af hele strækningen, fra Tyrkiet og Israel til Indien og Indonesien. Irak og Afghanistan ligger i hjertet af denne region. Om disse lande i sidste ende selv bliver til stabile demokratier, eller vi lader dem synke tilbage i kaos og ekstremisme vil ikke blot afgøre skæbnen for denne kritisk vigtige del af verden, men også afgøre vor egen skæbne.

\section{Irak tager tid}

Det er igennem dette brede strategiske initiativ at vi må forstå vore bestræbelser i Irak og Afghanistan. Mange mennesker spørger, hvordan vi skal definere vore succeskriterier. Succes i Irak og Afghanistan vil sige at etablere fredelige, stabile, velstående og demokratiske stater, som ikke udgør nogen trussel for deres naboer og bidrager til terroristernes nederlag. Succes er den religiøse tolerances triumf over den voldelige radikalisme.

De, som hævder, at vore mål i Irak, ikke kan nås, tager fejl, ganske som de tog fejl, da for et år siden fejlagtigt erklærede, at krigen i Irak allerede var tabt. Siden juni 2007 er den dødbringende vold mod civile 
faldet med over 70 procent. Koalitionsstyrkernes tab er faldet med omkring 70 procent. Den dramatiske mindskelse af volden har åbnet vej for en tilbagevenden til noget, der mere ligner en normal politisk og $\varnothing$ konomisk tilværelse for gennemsnitsirakeren. Folk er igen begyndt at gå på arbejde. Markederne er åbne. Olieindtægterne stiger hastigt. Inflationen er i bund. Iraks økonomi forventes at vokse med omkring syv procent i 2008. Politisk forsoning finder sted over hele Irak på lokalt græsrodsniveau og i provinserne. De sunni- og shiamuslimer, som blev jaget bort fra deres hjem, er nu på vej tilbage igen. De politiske fremskridt på det nationale niveau er sket $\mathrm{i}$ alt for langsomt tempo, men fremskridt er blevet gjort.

Kritikere siger, at troppe-'optrapningen' ikke er nogen løsning i sig selv, men at vi må skabe de fremskridt, der er nødvendige for, at Irak kan stå på egne ben. Det er jeg enig i. Irakerne selv må i stigende grad tage ansvar for deres egen sikkerhed, og de må blive ansvarlige politiske aktører. Det følger imidlertid ikke heraf, at vi hovedkuls skal trække os ud af Irak uden hensyn til konsekvenserne. Vi må vælge forsigtighedens og ansvarlighedens kurs og hjælpe irakerne til at komme nærmere den dag, hvor de ikke længere behøver vor hjælp.

Dette er det ansvarlige statsmandskabs vej. Vi har pådraget os et moralsk ansvar i Irak. Det vil være en skruppelløs og forræderisk handling og efterlade en skamplet på vor nations karakter, hvis vi lod det irakiske folk i stikken og overlod dem til gruopvækkende vold, etnisk udrensning og muligvis folkemord, som ville efterfølge en samvittighedsløs, uansvarlig og forhastet tilbagetrækning. Vore kritikere siger, at Amerika er nødt til at råde bod på sit ry i verden. Hvordan kan de samtidig være fortalere for en moralsk dadelværdig flugt fra vort ansvar i Irak?

De, som hævder, at vi kan trække os ud fra Irak for at bekæmpe alQaeda mere effektivt andre steder, begår en farlig fejltagelse. Om alQaeda var der før eller ej, så befinder al-Qaeda sig i Irak nu, ligesom det befinder sig i grænselandet mellem Pakistan og Afghanistan, i Somalia og Indonesien.

Hvis vi trækker os overilet ud af Irak, vil al-Qaeda i Irak overleve, proklamere sejr og fortsætte med at fremprovokere sekteriske spændinger, som stadig eksisterer, skønt de er blevet trængt tilbage af optrapningens succes, eftersom de forskellige fraktioner af sunnier og shiitter endnu ikke har overvundet deres gamle gensidige had og endnu er modtagelige for at blive provokeret af al-Qaeda. Borgerkrig i Irak vil hurtigt kunne udvikle sig til folkemord og destabilisere hele regionen, når nabomagter kommer deres foretrukne fraktioner til undsætning. Efter min mening vil en hensynsløs og overilet tilbagetrækning 
blive et forfærdeligt tilbageslag for vore sikkerhedsinteresser og vore værdier.

Iran vil også se vor overilede tilbagetrækning som en sejr, og som den største statssponsor af terrorister, et land med atomare ambitioner og et erklæret ønske om at ødelægge staten Israel, vil det se sin indflydelse i Mellemøsten vokse betydeligt. Konsekvenserne af at lide et sådant nederlag vil true os i år fremover, og de, som er fortalere for det, således som begge demokratiske kandidater er, er fortalere for en kurs, der i sidste ende vil trække os ind i en mere omfattende og mere vanskelig krig, der vil indebære langt større farer og ofre, end vi til dato har været ude for

Jeg taler ikke for et fortsat engagement i Irak - lige så lidt som jeg for nogle år siden ikke talte imod de forandringer i taktik og den indsættelse af de yderligere styrker, som nu er ved at skabe gode resultater i Irak - fordi jeg på en eller anden måde er ligeglad med krig og de lidelser, den medfører for alt for mange amerikanske familier. Jeg fastholder mit standpunkt: Jeg hader krig, og jeg ved udmærket og har selv meget personlige erfaringer for, hvor smertelige dens omkostninger er, men jeg ved også, at vi undertiden bliver nødt til at betale disse omkostninger for at undgå at betale endnu højere omkostninger senere.

Jeg stiller op til præsident, fordi jeg ønsker at holde det land jeg elsker og har tjent i hele mit liv, sikkert og for at imødegå vor tids udfordringer, som generationer før os var rede til at imødegå deres. Jeg stiller op til præsident, fordi jeg ved, at det mere end nogen anden nation på Jorden påhviler Amerika at føre an i opbyggelsen af grundlaget for en stabil og varig fred, en fred, der bygger på styrken i vore forpligtelse på fred, på de transformative idealer, hvorpå vi grundede vor nation, på vor evne til at se rundt om historiens næste hjørne og på vort mod og visdom til at træffe vanskelige valg. Jeg stiller op, fordi jeg har en tro, der er stærkere end nogensinde på, at det i vor tid står i vor magt at skabe en anden og bedre verden, end den vi overtog.

Oversat af Niels Ivar Larsen. 